\title{
Mulinane and Azorellane Diterpenoid Biomarkers by GC-MS from a Representative Apiaceae (Umbelliferae) Species of the Andes
}

\author{
Bernd R.T. Simoneit ${ }^{1, *}$, Daniel R. Oros ${ }^{2}$, Rudolf Jaffé ${ }^{3}$ (i), Alexandra Didyk-Peña ${ }^{4, *}$, \\ Carlos Areche ${ }^{5}$, Beatriz Sepúlveda ${ }^{6}$ and Borys M. Didyk ${ }^{7}$ \\ 1 Department of Chemistry, College of Science, Oregon State University, Corvallis, OR 97331, USA \\ Consultant, 72 Marina Lakes Drive, Richmond, CA 94804, USA; daniel.r.oros@gmail.com \\ 3 Southeast Environmental Research Center and Department of Chemistry and Biochemistry, \\ Florida International University, 3000 NE 151st Street, North Miami, FL 33181, USA; jaffer@fiu.edu \\ 4 Escuela de Química y Farmacia, Facultad de Medicina, Universidad Andres Bello, \\ Viña del Mar 2520000, Chile \\ 5 Departamento de Química, Facultad de Ciencias, Universidad de Chile, Casilla 653, Santiago 8320000, Chile; \\ areche@uchile.cl \\ 6 Departamento de Ciencias Químicas, Universidad Andres Bello, Viña del Mar 2520000, Chile; \\ bsepulveda@uc.cl \\ 7 Consultant, Casilla 942, Viña del Mar 2520000, Chile; bmdidyk@gmail.com \\ * Correspondence: simonebe@oregonstate.edu (B.R.T.S.); maria.didyk@unab.cl (A.D.-P.); \\ Tel.: +1-541-737-2081 (B.R.T.S.)
}

Academic Editor: Motoo Tori

check for updates

Received: 16 January 2019; Accepted: 13 February 2019; Published: 14 February 2019

\begin{abstract}
Extracts of bled resin from Azorella compacta, of the Azorelloideae family from the Andes $(>4000 \mathrm{~m})$, were analyzed by gas chromatography-mass spectrometry. The mass spectra of the dominant compounds of the resin and its hydrogenation products were documented. The most abundant compounds were oxygenated diterpenoids, namely mulinadien-20-oic $\left(\Delta^{11,13}\right.$ and $\left.\Delta^{11,14}\right)$ acids, azorell-13-en-20-oic acid, 13 $\alpha, 14 \beta$-dihydroxymulin-11-en-20-oic acid, and azorellanol, with a group of azorellenes and mulinadienes. The mass spectra of the novel diterpenoid hydrocarbons with the azorellane and mulinane skeletons were also presented. This study documents the molecular diversity of these diterpenoid classes, and could be of great utility for future organic geochemical, environmental, archeological, pharmaceutical, and forensic chemistry studies.
\end{abstract}

Keywords: Azorella compacta; diterpenoids; GC-MS; standards

\section{Introduction}

Natural products or their derivatives in the ambient environment or geological record are used by organic geochemists as tracers for sources, transport and alteration processes of organic matter, e.g., [1-7]. Remote locales, for example, the high Andes region in South America, are ideal sites as pristine references for background studies of such processes. An early report on the lipids and biomarkers in sediment from Lake Lejia in a caldera in Antofagasta, Chile, found traces of diterpenoids typical of resinous vegetation [8]. The region is barren of trees, especially gymnosperms that produce resin, and potential sources such as the Araucariaceae grow far to the south [9]. Subsequently, we reported on the lipid and resin composition of a dried sample of Laretia compacta (common name Llareta) from San Pedro de Atacama [10]. The dried material had a strong resinous odor and thus was implied as a possible source of diterpenoids in the Altiplano environment. The extract yield of the whole plant based on dry weight comprised $4.2 \mathrm{mg} / \mathrm{g}(0.2 \%)$ lipids and $2.5 \mathrm{mg} / \mathrm{g}(0.12 \%)$ 
terpenoids [10]. The terpenoid distribution consisted of mono-, sesqui- and diterpenoids, and the latter are of interest here because tri- and tetracyclic diterpenoids were the dominant compounds.

Laretia compacta is now called Azorella compacta of the Apiaceae:Azorelloideae family, also known as Umbelliferae [11]. These plants grow slowly at high altitudes (>4000 $\mathrm{m}$ ) in the northern Andes of Chile and Peru as dense pillow-like structures close to the ground with subterranean stems and roots. The Azorelloideae family evolved from the first Umbelliferae during the Cretaceous, e.g., [12,13].

Azorella sp. have historically been used on the Altiplano as firewood and cooking fuel by local cultures, and later in early industrial and mining activities as fuel, which contributed to its scarcity and current protection. The species is now more common, and represents the dominant biomass in these Andean environments. The plants and resin exudates have been used by Andean cultures for medicinal purposes where, for example, hot water infusions serve as herbal remedies for various ailments [14,15]. Consequently, natural product characterization and pharmacological studies have been carried out on $A$. compacta and related species. Numerous investigations reported structure determinations and pharmacological potential studies of the resin compounds, that were isolated and purified from the major Andean Apiaceae species, namely Mulinum and Azorella [16-35]. This has led to a description of mainly two novel diterpenoid skeletons among the natural products, specifically the mulinanes and azorellanes (Figure 1), with the assignment of their skeletal numbering conventions [16,21]. The biosynthetic pathway for the mulinane and azorellane diterpenoids has been proposed as starting from a phytatetraene [24]. Laboratory syntheses of polar mulinane diterpenoids have also recently been reported $[36,37]$.

\section{Skeleton numbering convention}

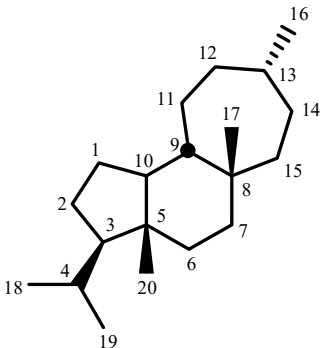

$13 \beta(\mathrm{H})-$ Mulinane

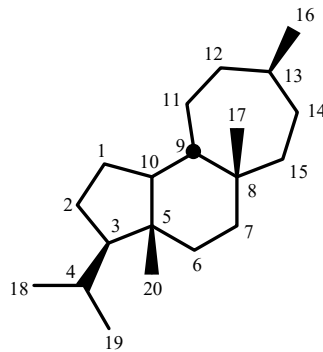

$13 \alpha(\mathrm{H})-$ Mulinane

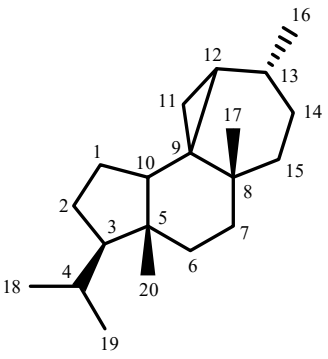

$13 \beta(\mathrm{H})$-Azorellane

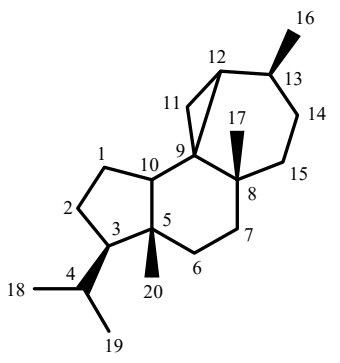

$13 \alpha(\mathrm{H})$-Azorellane

Figure 1. Carbon numbering convention for the mulinane and azorellane skeletons.

Here, we characterize the molecular composition of Azorella compacta resin based on mass spectrometric interpretation, and correlation and comparison with known standards. We report the mass spectra and gas chromatography-mass spectrometry (GC-MS) characteristics of the dominant compounds of the resin and of the hydrogenated resin as the free and derivatized products. This information is unique, because prior reports in the natural product literature only provided mass spectrometric data on some compounds. Our data further documents the molecular diversity of this novel diterpenoid class (mulinane and azorellane), information which could be of great utility for future organic geochemical, environmental, archeological, pharmaceutical, and forensic chemistry studies.

\section{Results and Discussion}

The relative composition of the fresh resin was 1\% sesquiterpenoid and $99 \%$ diterpenoids, excluding a low amount of bornyl acetate $(<0.5 \%)$. No lipid components from plant wax were detected. It is of interest to note the breakdown of the diterpenoids into $19 \%$ hydrocarbons and $80 \%$ polar oxygenated compounds, and the same proportions were retained upon hydrogenation. This observation was unexpected because most bled conifer resins are characterized by higher oxygenated diterpenoid contents (Simoneit, unpublished data). 
Typical examples of GC-MS total ion current traces for A. compacta resin and hydrogenated resin indicated the molecular complexity of the compound mixtures (Figure 2). The poor resolution of the underivatized resin acids (cf. Figure 2a) was due to their polarity. Sample components were classified into three groups of compounds, sesquiterpenoid, diterpenoid hydrocarbons and oxygenated diterpenoids, and are discussed as such. Only one sesquiterpenoid, namely spathulenol (I, all structures are shown in Appendix A), which hydrogenates to two isomers of spathulanol (II), was observed. The relative concentrations of all identified compounds are listed in Table 1.
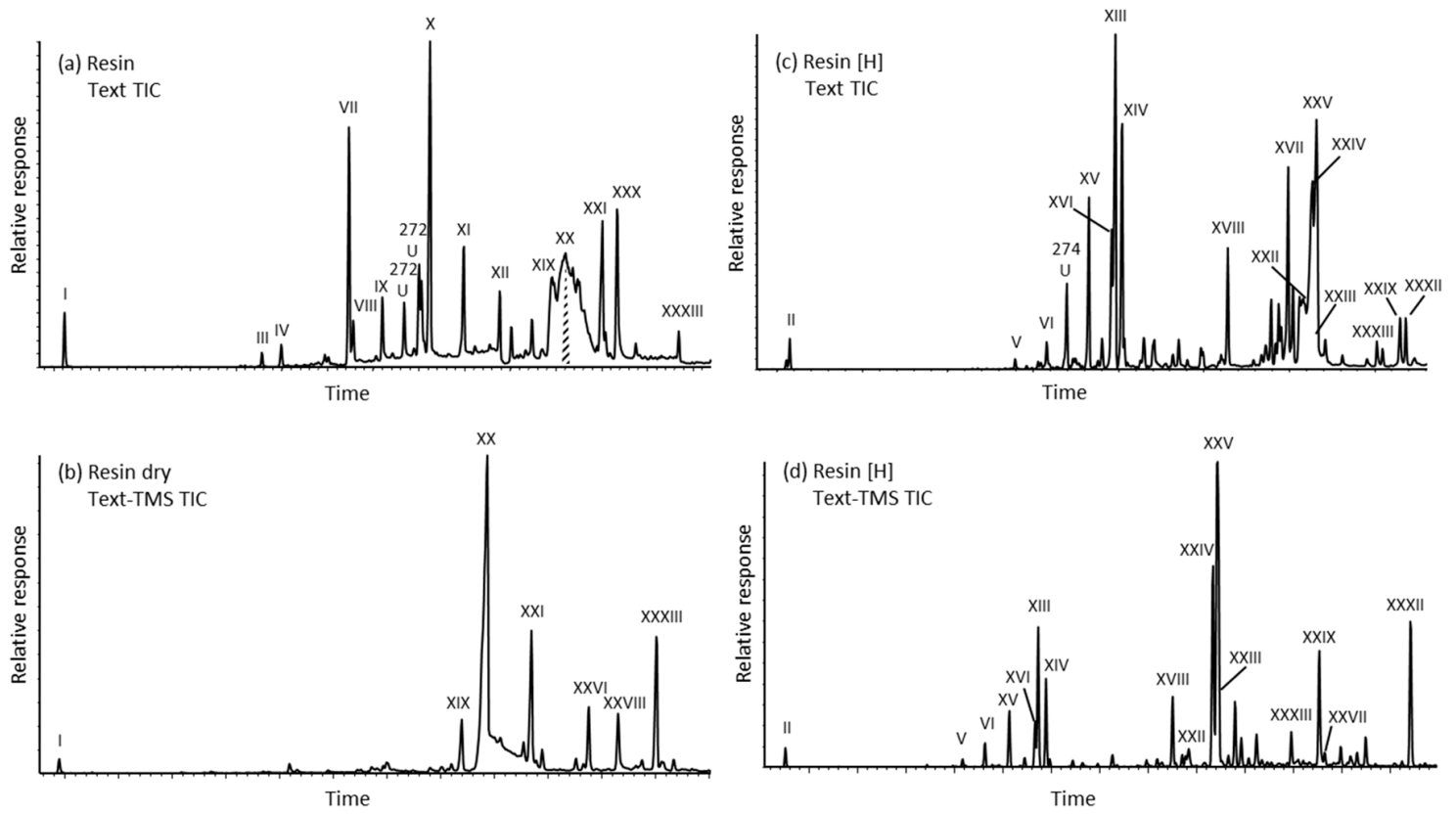

Figure 2. Examples of GC-MS total ion current traces for A. compacta resin and hydrogenated resin analyzed as: $(\mathbf{a}, \mathbf{c})$ total extracts, and $(\mathbf{b}, \mathbf{d})$ silylated extracts. Roman numerals refer to structures in Table 1 and Appendix A.

Table 1. Relative concentrations of the major compounds identified in resin and hydrogenated resin of Azorella compacta.

\begin{tabular}{|c|c|c|c|c|c|c|}
\hline $\begin{array}{l}\text { Structure } \\
\text { Number }^{\text {a }}\end{array}$ & Compound & Composition $^{b}$ & MW & ID $^{c}$ & $\operatorname{Resin}(n=7)$ & $\begin{array}{c}\text { Hydrogenated } \\
\text { Resin }(n=4)\end{array}$ \\
\hline I & Spathulenol & $\mathrm{C}_{15} \mathrm{H}_{24} \mathrm{O}$ & 220 & $\mathrm{~S}$ & 1.4 & \\
\hline II & Spathulanol & $\mathrm{C}_{15} \mathrm{H}_{26} \mathrm{O}$ & 222 & S & & 3 \\
\hline III & 20-Normulina-11,13-diene & $\mathrm{C}_{19} \mathrm{H}_{30}$ & 258 & $\mathrm{~T}$ & 0.5 & \\
\hline IV & 20-Norazorell-13-ene & $\mathrm{C}_{19} \mathrm{H}_{30}$ & 258 & $\mathrm{~T}$ & 1 & \\
\hline V & 20-Norazorellane, $\alpha+\beta$ & $\mathrm{C}_{19} \mathrm{H}_{32}$ & 260 & $\mathrm{~T}$ & & 1 \\
\hline VI & 20-Normulinane, $\alpha+\beta$ & $\mathrm{C}_{19} \mathrm{H}_{34}$ & 262 & $\mathrm{~T}$ & & 0.3 \\
\hline VII & $13 \beta(\mathrm{H})$-Azorell-14-ene & $\mathrm{C}_{20} \mathrm{H}_{32}$ & 272 & $\mathrm{~T}$ & 9 & \\
\hline VIII & Azorell-13-ene & $\mathrm{C}_{20} \mathrm{H}_{32}$ & 272 & I & 2 & \\
\hline IX & $13 \alpha(\mathrm{H})$-Azorell-14-ene & $\mathrm{C}_{20} \mathrm{H}_{32}$ & 272 & $\mathrm{~T}$ & 2.5 & \\
\hline X & 13ß(H)-Mulina-11,14-diene & $\mathrm{C}_{20} \mathrm{H}_{32}$ & 272 & I & 16 & \\
\hline XI & Mulina-11,13-diene & $\mathrm{C}_{20} \mathrm{H}_{32}$ & 272 & $\mathrm{~L}$ & 7 & \\
\hline XII & $13 \alpha(\mathrm{H})$-Mulina-11,14-diene & $\mathrm{C}_{20} \mathrm{H}_{32}$ & 272 & I & 4 & \\
\hline XIII & $13 \beta(\mathrm{H})$-Azorellane & $\mathrm{C}_{20} \mathrm{H}_{34}$ & 274 & I & & 26 \\
\hline XIV & $13 \alpha(\mathrm{H})$-Azorellane & $\mathrm{C}_{20} \mathrm{H}_{34}$ & 274 & I & & 15 \\
\hline XV & $13 \beta(\mathrm{H})$-Mulinane & $\mathrm{C}_{20} \mathrm{H}_{36}$ & 276 & I & & 11 \\
\hline XVI & $13 \alpha(\mathrm{H})$-Mulinane & $\mathrm{C}_{20} \mathrm{H}_{36}$ & 276 & I & & 8 \\
\hline XVII & 13-Hydroxyazorellanes & $\mathrm{C}_{20} \mathrm{H}_{34} \mathrm{O}$ & 290 & $\mathrm{~L}$ & & 14 \\
\hline XVIII & $13 \alpha$-Hydroxymulinane & $\mathrm{C}_{20} \mathrm{H}_{36} \mathrm{O}$ & 292 & $\mathrm{~L}$ & & 22 \\
\hline XIX & $13 \beta(\mathrm{H})$-Mulina-11,14-dien-20-oic acid & $\mathrm{C}_{20} \mathrm{H}_{30} \mathrm{O}_{2}$ & 302 & $\mathrm{~S}$ & 10 & \\
\hline $\mathrm{XX}$ & Mulina-11,13-dien-20-oic acid & $\mathrm{C}_{20} \mathrm{H}_{30} \mathrm{O}_{2}$ & 302 & $\mathrm{~S}$ & 100 & \\
\hline XXI & Azorell-13-en-20-oic acid & $\mathrm{C}_{20} \mathrm{H}_{30} \mathrm{O}_{2}$ & 302 & $\mathrm{~s}$ & 17 & \\
\hline XXII & $13 \beta(\mathrm{H})$-Azorellan-20-oic acid & $\mathrm{C}_{20} \mathrm{H}_{32} \mathrm{O}_{2}$ & 304 & S & & 5 \\
\hline XXIII & $13 \alpha(\mathrm{H})$-Azorellan-20-oic acid & $\mathrm{C}_{20} \mathrm{H}_{32} \mathrm{O}_{2}$ & 304 & $\mathrm{~s}$ & & 30 \\
\hline
\end{tabular}


Table 1. Cont.

\begin{tabular}{|c|c|c|c|c|c|c|}
\hline $\begin{array}{l}\text { Structure } \\
\text { Number }{ }^{\text {a }}\end{array}$ & Compound & Composition $^{b}$ & MW & ID $^{\mathrm{c}}$ & $\operatorname{Resin}(n=7)$ & $\begin{array}{c}\text { Hydrogenated } \\
\text { Resin }(n=4)\end{array}$ \\
\hline XXIV & $13 \beta(\mathrm{H})$-Mulinan-20-oic acid & $\mathrm{C}_{20} \mathrm{H}_{34} \mathrm{O}_{2}$ & 306 & $\mathrm{~S}$ & & 44 \\
\hline XXV & $13 \alpha(\mathrm{H})$-Mulinan-20-oic acid & $\mathrm{C}_{20} \mathrm{H}_{34} \mathrm{O}_{2}$ & 306 & S & & 100 \\
\hline XXVI & Mulinol & $\mathrm{C}_{20} \mathrm{H}_{34} \mathrm{O}_{2}$ & 306 & $\mathrm{~L}$ & 7 & \\
\hline XXVII & Dihydromulinol & $\mathrm{C}_{20} \mathrm{H}_{36} \mathrm{O}_{2}$ & 308 & I & & 6 \\
\hline XXVIII & $13 \alpha$-Hydroxymulin-11-en-20-oic acid & $\mathrm{C}_{20} \mathrm{H}_{32} \mathrm{O}_{3}$ & 320 & S & 8 & \\
\hline XXIX & $13 \alpha$-Hydroxymulinan-20-oic acid & $\mathrm{C}_{20} \mathrm{H}_{34} \mathrm{O}_{3}$ & 322 & S & & 25 \\
\hline$x X X$ & 20-Acetoxymulina-11,13-diene & $\mathrm{C}_{22} \mathrm{H}_{34} \mathrm{O}_{2}$ & 330 & $\mathrm{~L}$ & 15 & \\
\hline XXXI & $13 \alpha, 14 \beta$-Dihydroxymulin-11-en-20-oic acid & $\mathrm{C}_{20} \mathrm{H}_{30} \mathrm{O}_{4}$ & 336 & $\mathrm{~L}$ & 11 & \\
\hline XXXII & $13 \alpha, 14 \beta$-Dihydroxymulinan-20-oic acid & $\mathrm{C}_{20} \mathrm{H}_{34} \mathrm{O}_{4}$ & 338 & I & & 32 \\
\hline XXXIII & Azorellanol & $\mathrm{C}_{22} \mathrm{H}_{36} \mathrm{O}_{3}$ & 348 & $\mathrm{~L}$ & 16 & 12 \\
\hline
\end{tabular}

a Structures are shown in Appendix A. ${ }^{\mathrm{b}}$ Listed as the natural products, polar compounds analyzed as methyl esters and/or trimethylsilyl derivatives. ${ }^{\mathrm{c}}$ Identification: $\mathrm{I}=$ interpretation and correlation of MS fragmentation pattern and GC retention time as derivative from standard, $\mathrm{T}=$ suggested interpretation based on MS and GC retention time only, $\mathrm{S}=$ standard, $\mathrm{L}=$ literature citation, $\mathrm{n}=$ number of analyses.

\subsection{Diterpenoid Hydrocarbons}

There were two norditerpenes, 20-normulina-11,13-diene (III) and 20-norazorell-13-ene (IV), which upon hydrogenation yielded four isomers, namely 20-normulinane (VI) and 20-norazorellane (V) both as the $13 \beta(\mathrm{H})$ and $13 \alpha(\mathrm{H})$-epimers (Figure 3a-f, also see Figure SM-2b). We inferred the absence of C-20 for these novel norditerpenes, rather than C-16 or C-17, based on the facile elimination of the functionalized C-20 group in the mass spectra of the acid standards discussed below. The configuration at C-5 is most likely $5 \beta(\mathrm{H})$, but based on the preferential loss or absence of a C-20 functional group, could also be represented as $5 \alpha(\mathrm{H})$.
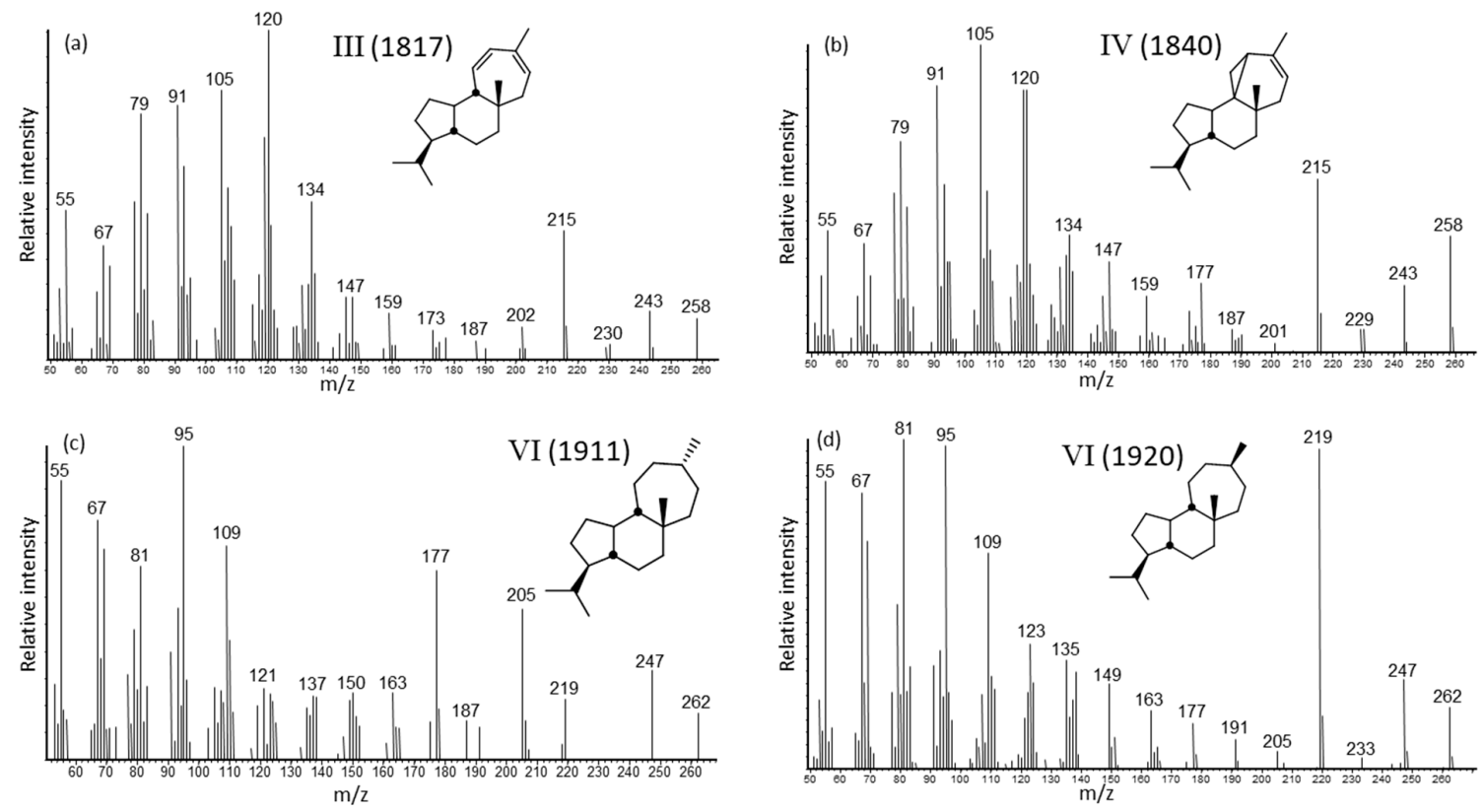

Figure 3. Cont. 

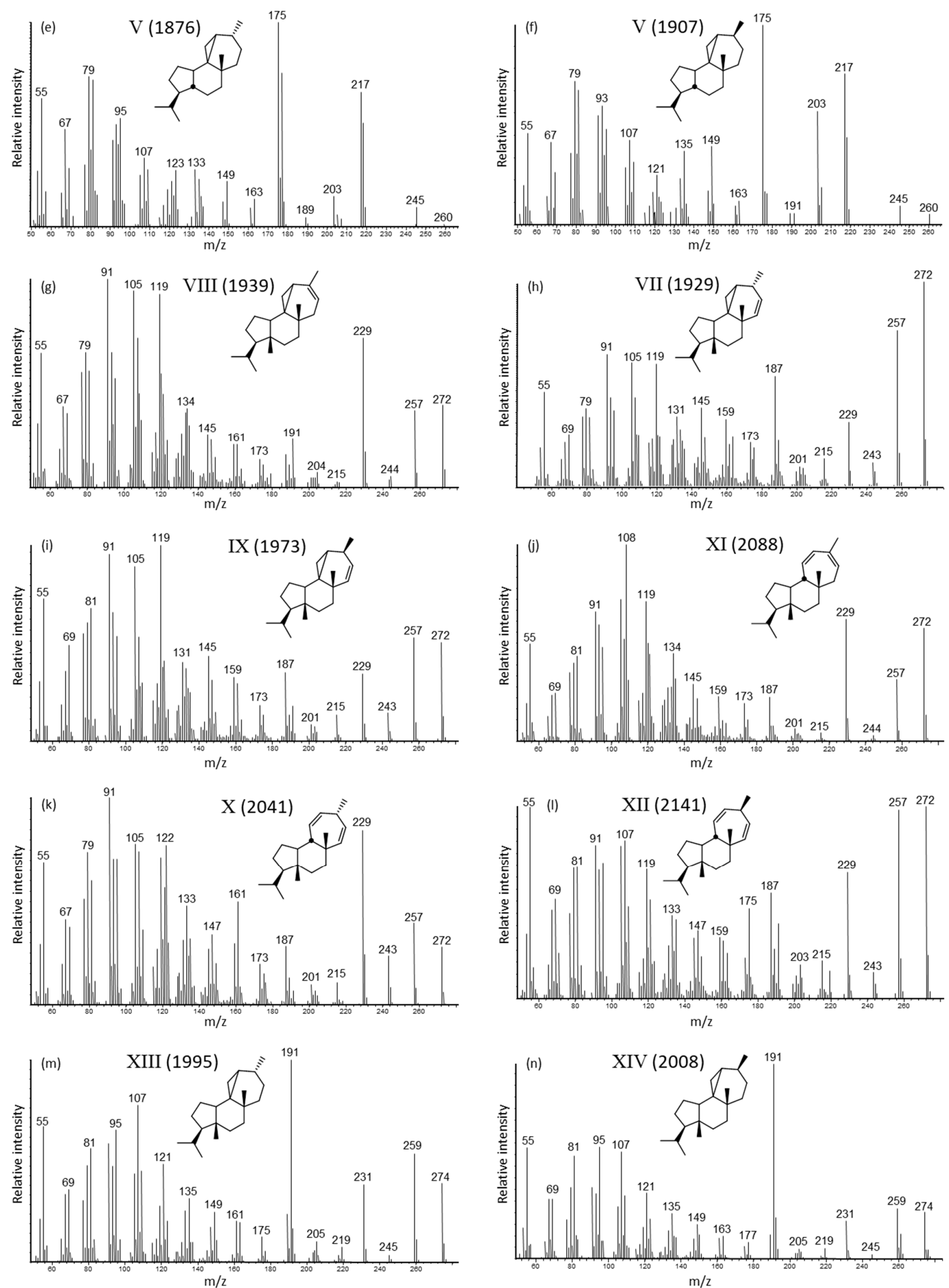

Figure 3. Cont. 

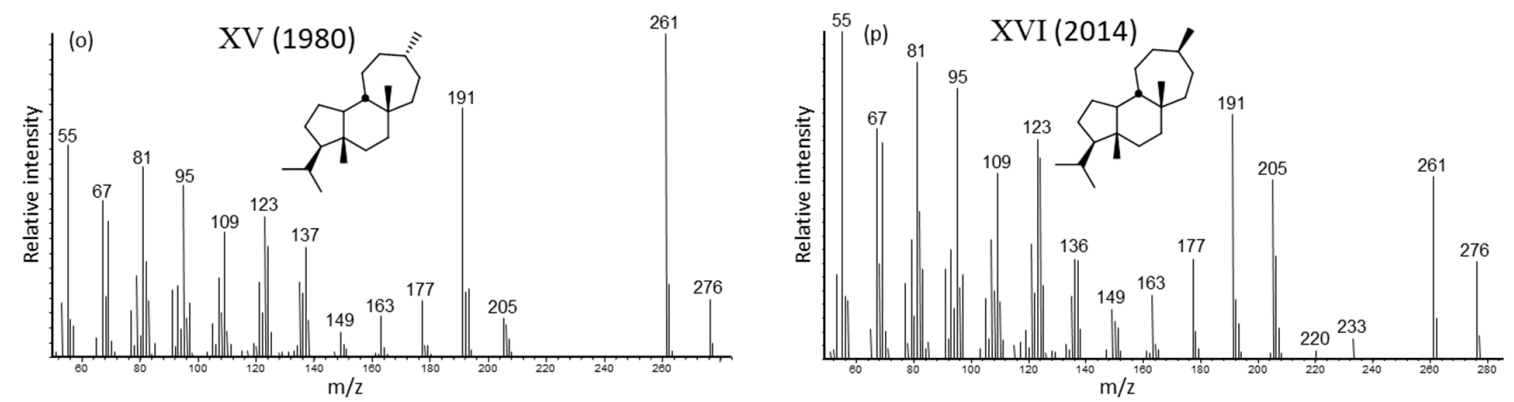

Figure 3. Mass spectra of the diterpenoid hydrocarbons in A. compacta resins. The KI values relative to $n$-alkanes on a DB-5 column are shown in parentheses on each mass spectrum: (a) 20-normulina-11,13-diene (III), (b) 20-norazorell-13-ene (IV), (c) 13ß(H)-20-normulinane (VI), (d) $13 \alpha(\mathrm{H})$-20-normulinane (VI), (e) 13ß(H)-20-norazorellane (V), (f) $13 \alpha(\mathrm{H})$-20-norazorellane (V), (g) azorell-13-ene (VIII), (h) 13ß(H)-azorell-14-ene (VII), (i) $13 \alpha(\mathrm{H})$-azorell-14-ene (IX), (j) mulina-11,13-diene (XI), (k) 13 $\beta(\mathrm{H})$-mulina-11,14-diene (X), (1) 13 $\alpha(\mathrm{H})$-mulina-11,14-diene (XII), (m) $13 \beta(\mathrm{H})$-azorellane (XIII), (n) $13 \alpha(\mathrm{H})$-azorellane (XIV), (o) 13ß(H)-mulinane (XV), and (p) $13 \alpha(\mathrm{H})$-mulinane $(\mathrm{XVI})$.

There were six isomers of $\mathrm{C}_{20}$ diterpene hydrocarbons, which after hydrogenation yielded four isomers of the saturated diterpanes. The interpretations of the mass spectra as mulina-11,13-diene $(\mathrm{XI}), 13 \beta(\mathrm{H})$-mulina-11,14-diene $(\mathrm{X})$ and $13 \alpha(\mathrm{H})$-mulina-11,14-diene (XII) (Figure 3j-1) were inferred from the literature [32], although the match was poor. The identifications of azorell-13-ene (VIII), $13 \beta(\mathrm{H})$-azorell-14-ene (VII) and $13 \alpha(\mathrm{H})$-azorell-14-ene (IX) were based on the GC elution order and interpretations of the mass spectrometric fragmentation patterns (Figure $3 \mathrm{~g}-\mathrm{i}$; details are given in Figure SM-2b) when compared to the C-20 functionalized standards.

Upon hydrogenation to the mulinane and azorellane skeletons (Figure 1), we obtained two isomers, i.e., $13 \alpha(\mathrm{H})$ and $13 \beta(\mathrm{H})$, for the position of the methyl group at $\mathrm{C}-13$. We assigned the elution order as was observed for the $\alpha$ and $\beta$ kaurane and phyllocladane standards [38,39], that is the $13 \beta(\mathrm{H})$ isomer eluted prior to the $13 \alpha(\mathrm{H})$ epimer. The diterpanes, namely $13 \beta(\mathrm{H})$-azorellane (XIII), $13 \alpha(\mathrm{H})$-azorellane (XIV), $13 \beta(\mathrm{H})$-mulinane (XV), and $13 \alpha(\mathrm{H})$-mulinane (XVI), have similar mass spectra (Figure $3 \mathrm{~m}-\mathrm{p}$ ), but different molecular weights. The key ion for all is $m / z 191$, with $\mathrm{M}-\mathrm{C}_{3} \mathrm{H}_{7}$ $(m / z 231)$ for the azorellanes and $\mathrm{M}_{-} \mathrm{C}_{5} \mathrm{H}_{11}(\mathrm{~m} / z$ 205) for the mulinanes (cf. Figure SM-2b). These four compounds may be potential biomarkers for the geologic record and of interest to organic geochemistry. The mass spectra of both $\mathrm{C}_{20}$ hydrocarbon groups are the first report of these novel parent diterpenoid skeletons, and they do not match with any mass spectra of other reported tri- and tetracyclic diterpanes (e.g., abietanes, atisanes, pimaranes, kauranes, phyllocladanes, etc.).

\subsection{Oxygenated Diterpenoids}

The oxygenated diterpenoids comprised mainly mulina-11,13-dien-20-oic acid (XX) with the isomers $13 \beta(\mathrm{H})$-mulina-11,14-dien-20-oic (XIX) and azorell-13-en-20-oic (XXI) acids. Their identification was based on comparison of the mass spectra of standard natural products as the free and derivatized compounds (Figure $4 \mathrm{~d}-\mathrm{f}, \mathrm{k}-\mathrm{o}$ and Figure SM-1o-p, respectively), and their respective GC retention indices. One characteristic of the mass spectra of all C-20 carboxylic acids and C-20 methyl or TMS carboxylates is the facile loss of that moiety from the respective molecular ion (cf. Figure SM-2a). 

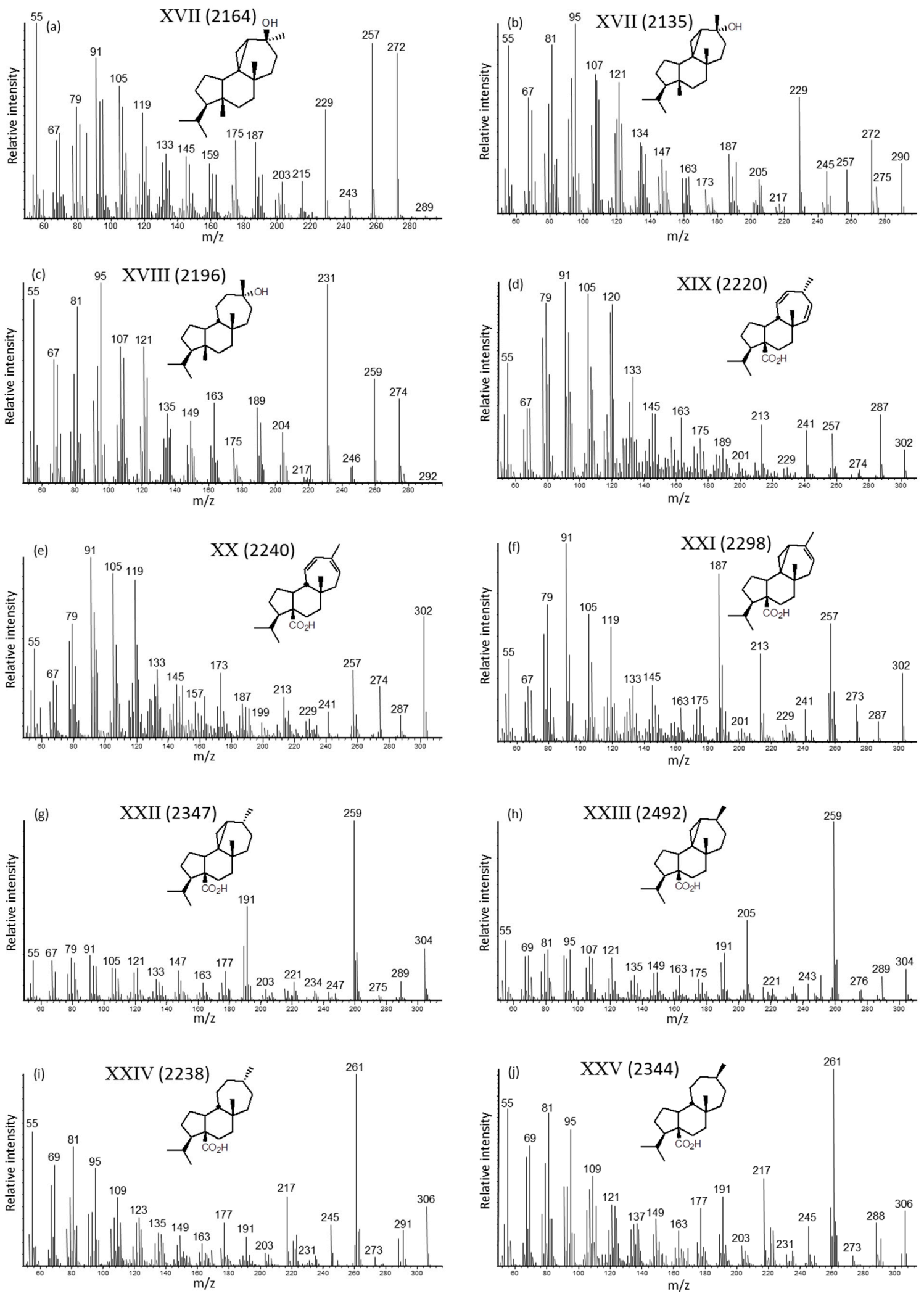

Figure 4. Cont. 

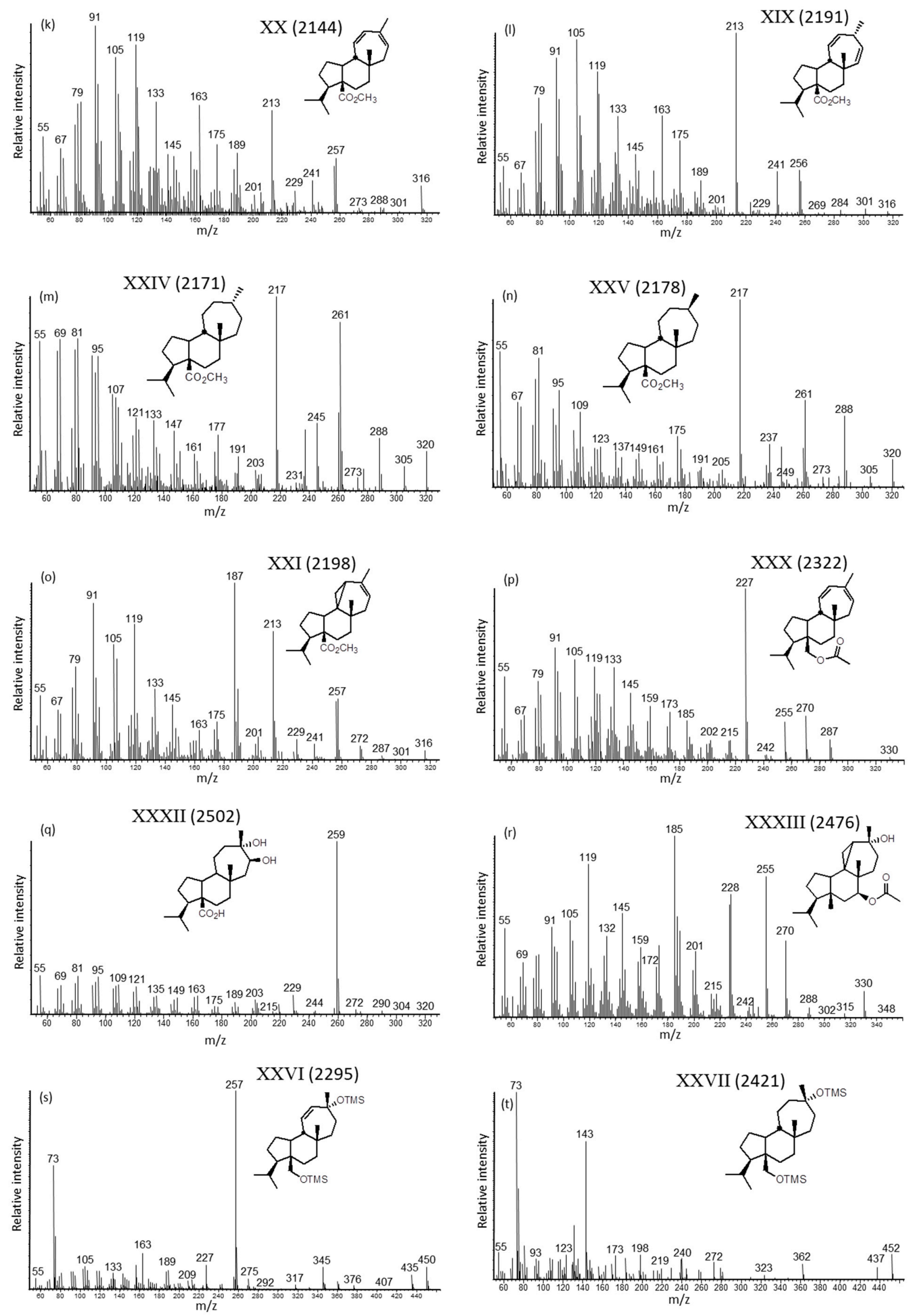

Figure 4. Cont. 

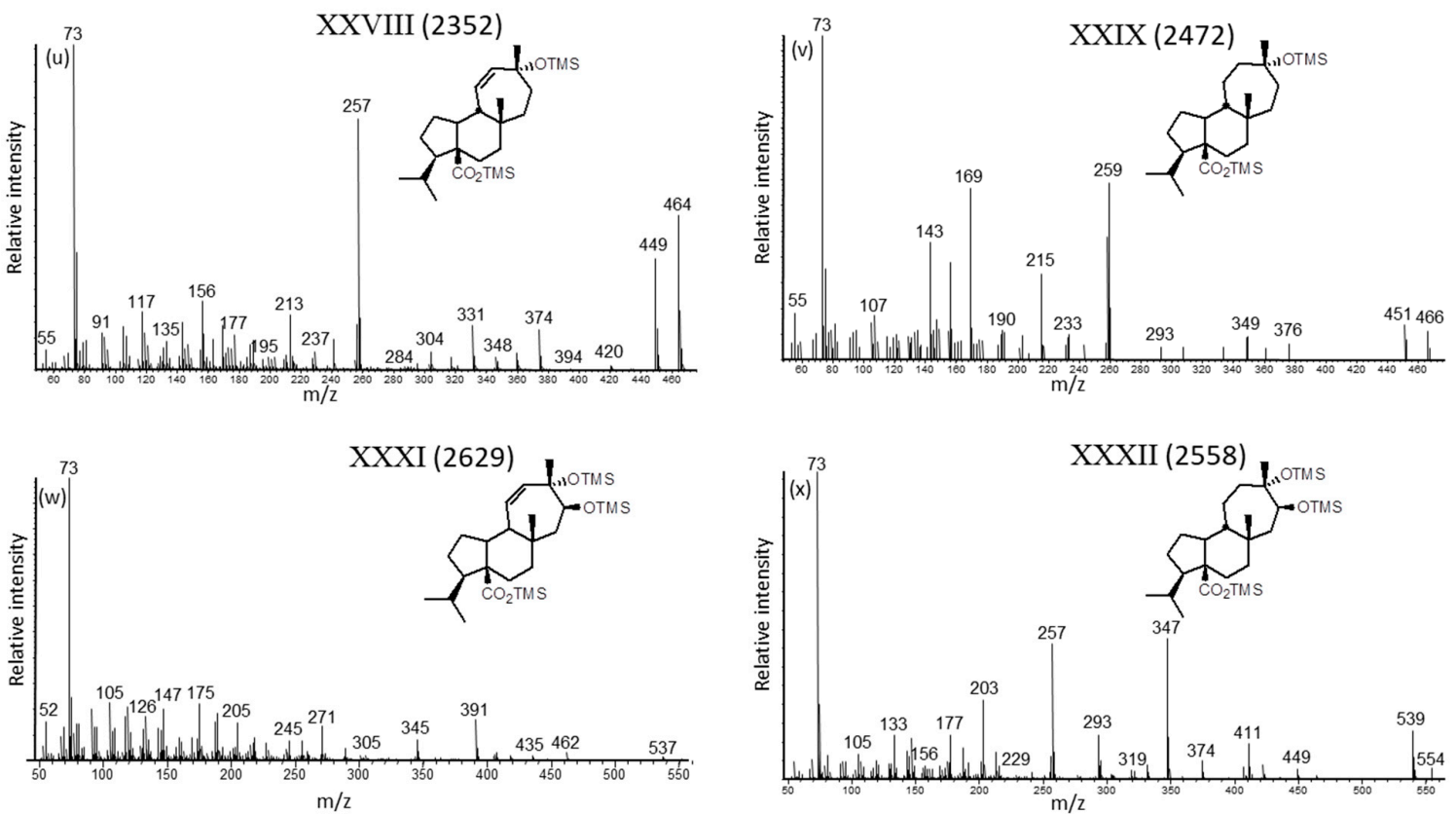

Figure 4. Mass spectra of the oxygenated diterpenoids in A. compacta resins, including KI values shown in parentheses: (a) 13 $\beta$-hydroxyazorellane (XVII), (b) 13 $\alpha$-hydroxyazorellane (XVII), (c) 13 $\alpha$-hydroxymulinane (XVIII), (d) 13 $\beta(\mathrm{H})$-mulina-11,14-dien-20-oic acid (XIX, standard), (e) mulina-11,13-dien-20-oic acid (XX, standard), (f) azorell-13-en-20-oic acid (XXI, standard), (g) $13 \beta(\mathrm{H})$-azorellan-20-oic acid (XXII, standard), (h) 13 $\alpha(\mathrm{H})$-azorellan-20-oic acid (XXIII, standard), (i) $13 \beta(\mathrm{H})$-mulinan-20-oic acid (XXIV, standard), (j) 13 $\alpha(\mathrm{H})$-mulinan-20-oic acid (XXV, standard), (k) methyl mulina-11,13-dien-20-oate (XX, standard), (1) methyl 13 $\beta(\mathrm{H})$-mulina-11,14-dien-20-oate (XIX, standard), (m) methyl 13 $\beta(\mathrm{H})$-mulinan-20-oate (XXIV, standard), (n) methyl 13 $\alpha(\mathrm{H})$-mulinan-20-oate (XXV, standard), (o) methyl azorell-13-en-20-oate (XXI, standard), (p) 20-acetoxymulina-11,13-diene $(X X X),(q) 13 \alpha, 14 \beta$-dihydroxymulinan-20-oic acid (XXXII), (r) azorellanol (XXXIII, standard), (s) mulinol-diTMS (XXVI), (t) dihydomulinol-diTMS (XXVII), (u) 13 $\alpha$-hydroxymulin-11-en-20-oic acid-diTMS (XXVIII, mulinolic acid-diTMS, standard), (v) 13 $\alpha$-hydroxymulinan-20-oic acid-diTMS (XXIX, standard), (w) 13 $\alpha, 14 \beta$-dihydroxymulin-11-en-20-oic acid-triTMS (XXXI), and (x) $13 \alpha, 14 \beta$-dihydroxymulinan-20-oic acid-triTMS (XXXII).

Significant amounts of 20-acetoxymulina-11,13-diene (XXX), azorellanol (7 $\beta$-acetoxy-13 $\alpha$-hydroxyazorellane, XXXIII), and 13 $\alpha, 14 \beta$-dihydroxymulin-11-en-20-oic acid (XXXI) were also identified. The major fragment ions of the mass spectrum of 20-acetoxymulina-11,13-diene (Figure 4p) matched with those listed in the literature for its direct insertion probe mass spectrum [26]. The mass spectrum of the azorellanol standard (Figure $4 \mathrm{r}$ and Figure SM- $1 \mathrm{v}$ as the TMS derivative) matched with its literature listing [21]. There was also a trace of the tentatively identified 13-epi-azorellanol (Figure SM-1k), which eluted prior to azorellanol. The structure of $13 \alpha, 14 \beta$-dihydroxymulin-11-en-20-oic acid (Figure $4 \mathrm{w}$ ) was based on correlation with the standard $13 \alpha$-hydroxy-14-oxomulin-11-en-20-oic acid (XXXIV, Figure SM-1j,w,z). Mulinol (13 $\alpha, 20$-dihydroxymulin-11-ene, XXVI) and 13 $\alpha$-hydroxymulin-11-en-20-oic acid (mulinolic acid, XXVIII) were observed as minor components. The mass spectrum of mulinol (Figure 4s) was correlated with that of its hydrogenation product (Figure 4v) and the published MS listing [20]. The mass spectra of mulinolic acid matched with those of the standard (Figure $4 u$ and Figure SM-1d,h). 
The hydrogenated resin sample contained the corresponding saturated diterpenoids (Figure 2c,d). As discussed above for the hydrocarbons, the elution order assumed for the dominant $13 \beta(\mathrm{H})$ - and $13 \alpha(\mathrm{H})$-mulinan-20-oic acids (XXIV and XXV, respectively) was beta before alpha (Figure 4i,j,m,n and Figure SM-1r,s, respectively). The same was the case for the $13 \beta(\mathrm{H})$ - and $13 \alpha(\mathrm{H})$-azorellan-20-oic acids (XXII and XXIII, respectively) and their mass spectra are shown in Figure 4g,h and Figure SM-1r,s, respectively (refer to Figure SM-2a). These diterpanoid acids may be potential diagenetic products in the geologic record and thus are of interest to organic geochemistry. The hydrogenation products of mulinol and dihydroxymulin-11-en-20-oic acid were also detectable as dihydromulinol (XXVII, Figure $4 \mathrm{t}$ ) and $13 \alpha, 14 \beta$-dihydroxymulinan-20-oic acid (XXXII, Figure 4x).

\section{Samples and Experimental Methods}

A sample of $A$. compacta resin was obtained by cutting to bleed an Azorella compacta plant growing off the road B245 from El Tatio to San Pedro de Atacama in the Paso la Vizcacha (Chile, Region II, $22^{\circ} 22^{\prime} 34^{\prime \prime} \mathrm{S}, 68^{\circ} 1^{\prime} 0^{\prime \prime} \mathrm{W}$, altitude $4556 \mathrm{~m}$ ).

The fresh resin was split into two parts, one dissolved completely in dichloromethane/methanol (DCM/MeOH, 3:1 v/v), and the duplicate sample was dissolved in $n$-hexane. Aliquots $(50 \mu \mathrm{L})$ of these total extracts were converted to trimethylsilyl derivatives by reaction with N,O-bis-(trimethylsilyl)trifluoroacetamide (BSTFA, Sigma-Aldrich, St. Louis, MO, USA) and pyridine for $3 \mathrm{~h}$ at $70^{\circ} \mathrm{C}$, e.g., [40]. Prior to analysis, the excess silylating reagent was evaporated by nitrogen blow down and the sample mixture dissolved in an equivalent volume of $n$-hexane. Other aliquots of sample solutions were treated with trimethylsilyldiazomethane (2M in hexane, Sigma-Aldrich) at room temperature for $30 \mathrm{~min}$ to methylate carboxylic acids [41]. The excess reagent was reacted with concentrated acetic acid, the solution dried by nitrogen blow down, and the products dissolved in $\mathrm{DCM} / \mathrm{MeOH}$ (3:1) for analysis.

The following reference standards were also derivatized and analyzed by these methods: spathulenol (I), mulina-11,13-dien-20-oic acid (XX), azorell-13-en-20-oic acid (XXI), 13 $\alpha$-hydroxymulin-11-en-20-oic acid (XXVIII), azorellanol (XXXIII), $13 \alpha$-hydroxy-14-oxomulin-11-en-20-oic acid (XXXIV), 7 $\beta, 13 \alpha$-dihydroxymulin-11-ene (XXXV), $15 \alpha$-acetoxymulina-11,13-dien-20-oic acid (XXXVI), and 18-acetoxymulina-11,13-diene-16,20-dioic acid (XXXVII).

Aliquots of the total extracts and mulina-11,13-dien-20-oic acid were hydrogenated. The samples were diluted with $\mathrm{DCM} / \mathrm{MeOH}(3: 1)$ in a round bottom flask (50 mL) with a magnetic stir bar and $\mathrm{PtO}_{2}$ (Arcos Organics, Fisher, Pittsburgh, PA, USA, 83\% Pt) as catalyst. $\mathrm{H}_{2}$ at atmospheric pressure was installed with a latex balloon $(500 \mathrm{~mL})$ over the neck of the flask and hydrogenation allowed to proceed at room temperature for $8 \mathrm{~h}$. The catalyst was filtered off and the sample concentrated by nitrogen blow down for analysis. 
The gas chromatography-mass spectrometry (GC-MS) analyses of the total extracts and aliquots of the derivatized and hydrogenated total extracts (typical injection volume $1 \mu \mathrm{L}$ ) were performed on a Hewlett-Packard model 6890 GC coupled to a Hewlett-Packard model 5973 MSD (Palo Alto, CA, USA)). Separation of compounds was achieved on a fused silica capillary column coated with DB-5MS (Agilent, Santa Clara, CA, USA) $30 \mathrm{~m} \times 0.25 \mathrm{~mm}$ i.d., $0.25 \mu \mathrm{m}$ film thickness). The GC operating conditions were as follows: temperature held at $65^{\circ} \mathrm{C}$ for $2 \mathrm{~min}$, increased from 65 to $300{ }^{\circ} \mathrm{C}$ at a rate of $6{ }^{\circ} \mathrm{C} \mathrm{min}-1$, and final isothermal held at $300^{\circ} \mathrm{C}$ for $20 \mathrm{~min}$. Helium was used as carrier gas. The samples were injected splitless with the injector temperature at $280^{\circ} \mathrm{C}$. The mass spectrometer was operated in the electron impact mode at $70 \mathrm{eV}$ and scanned from 50 to $650 \mathrm{da}$. Data were acquired and processed with the Chemstation software (Hewlett-Packard, Palo Alto, CA, USA). Compounds were identified by comparison of mass spectra and retention times with those of authentic standards, with literature data, and interpretation of mass spectrometric fragmentation patterns of unknowns. The Kovats [42] GC retention indices (KI) relative to $n$-alkanes are shown on each mass spectrum and are determined for elution on a DB-5 capillary column.

The extract of the dried plant (prior report by [10]) was reanalyzed. The dominant diterpenoids were the same as found in the new resin sample and are not discussed further.

\section{Conclusions}

In this study, we document the molecular characteristics and diversity of novel diterpenoid classes of natural products, namely mulinanes and azorellanes, from resin of the Andean Apiaceae plant species Azorella compacta. The dominant compounds were oxygenated diterpenoids, mainly mulinadien-20-oic $\left(\Delta^{11,13}\right.$ and $\left.\Delta^{11,14}\right)$ acids, azorell-13-en-20-oic acid, $13 \alpha, 14 \beta$-dihydroxymulin-11-en-20-oic acid, and azorellanol, as confirmed by standards. The diterpenoid hydrocarbons included mulinadienes and azorellenes, which are novel compounds of potential interest to organic geochemistry. The mulinane and azorellane diterpenoid hydrocarbons, resulting from the hydrogenation of the resin, may be potential biomarkers for the geologic record, while the corresponding oxygenated diterpenoids may be applied for environmental studies.

Supplementary Materials: Additional mass spectra of related and derivatized natural products are collected in the Supplemental Materials section available with this article.

Author Contributions: B.R.T.S. and B.M.D. conceived and designed the work; B.R.T.S., R.J., C.A. and B.S. performed the experiments; B.R.T.S. and D.R.O. analyzed and interpreted the data; B.R.T.S. wrote the paper, and all coauthors reviewed and edited the paper.

Funding: This research received no external funding.

Acknowledgments: We thank Ljubomir Tomasevic for the bled resin sample, and Leszek Marynowski and S. Kurkiewicz for some GC-MS data. This is publication number 897 from the Southeast Environmental Research Center and Institute of Water and Environment at Florida International University.

Conflicts of Interest: The authors declare no conflicts of interest. 


\section{Appendix A}

\section{Appendix I}<smiles>C=C1CCC2[C@H]([C@H]3[C@@H]1CC[C@]3(C)O)C2(C)C</smiles>

I. Spathulenol

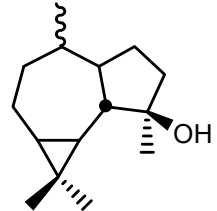

II. Spathulanols

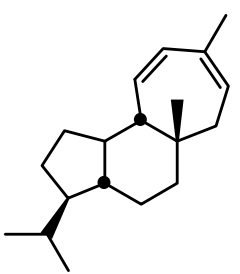

III. 20-Normulina -11,13-diene

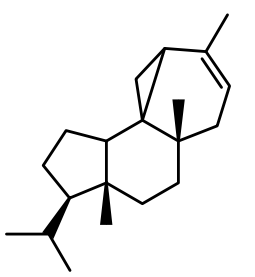

VIII. Azorell-13-ene

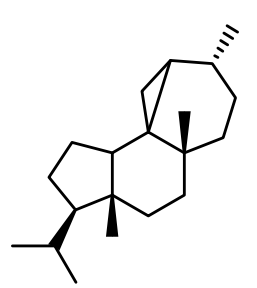

XIII. $13 \beta(H)-$ azorellane

$$
\text { -14-ene }
$$

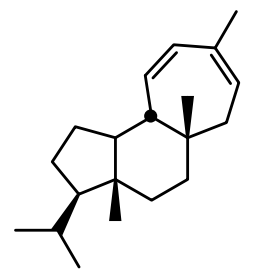

XI. Mulina-11,13 -diene

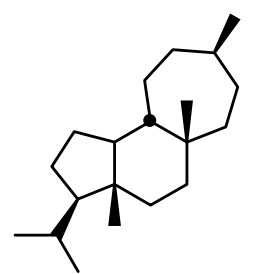

XVI. $13 \alpha(\mathrm{H})$ mulinane

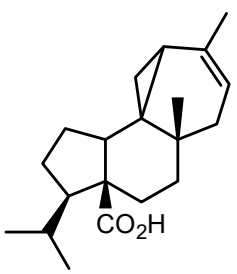

XXI. Azorell-13en-20-oic acid

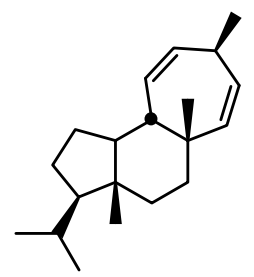

XII. $13 \alpha(\mathrm{H})$-mulina -11,14-diene<smiles>CC(C)[C@H]1CCC2C3CC4C[C@](C)(O)CC[C@]4(CC[C@@]21C)C3</smiles>

XVII. $13 \alpha-H y d r o x y-$ azorellane

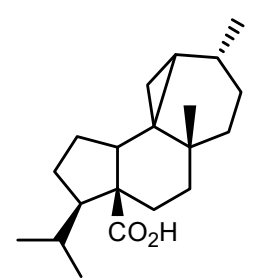

XXII. 13 $\beta(\mathrm{H})$-azorell- XXIII. $13 \alpha(\mathrm{H})$-azorellan-20-oic acid<smiles>CC(C)[C@H]1CC[C@H]2[C@@H]3CC[C@](C)(O)CC[C@]3(C)CC[C@@]21C</smiles>

XVIII. 13 $\alpha$-Hydroxy mulinane<smiles>CC(C)[C@H]1CCC2C34CC(C3)[C@@H](C)CC[C@]4(C)CC[C@]21C(=O)O</smiles>
an-20-oic acid

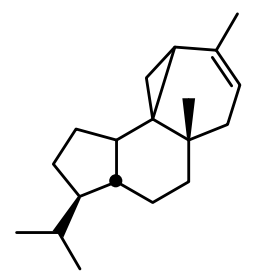

IV. 20-Norazorell -13-ene

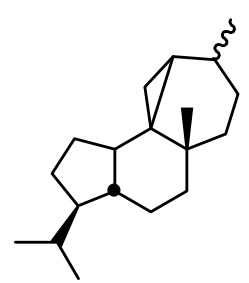

V. 20-Norazorellanes<smiles></smiles>

IX. $13 \alpha(\mathrm{H})$-azorell

-14-ene<smiles>CC(C)[C@H]1CCC2C34CC(C3C)[C@@H](C)CC[C@]4(C)CC[C@]21C</smiles>

XIV. $13 \alpha(\mathrm{H})-$ azorellane

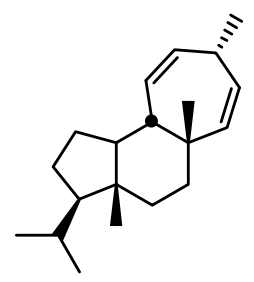

X. $13 \beta(\mathrm{H})$-mulina -11,14-diene<smiles>CC(C)[C@H]1CC[C@H]2C3CC[C@@H](C)CC[C@]3(C)CC[C@@]21C</smiles>

XV. $13 \beta(H)-$ mulinane

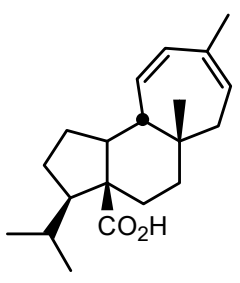

XIX. 13ß(H)-Mulina-11,14- XX. Mulina-11,13dien-20-oic acid<smiles>CC(C)[C@H]1CC[C@H]2C3CC[C@@H](C)CC[C@]3(C)CC[C@@]21C(=O)O</smiles>

XXIV. $13 \beta(\mathrm{H})$-mulinan-20-oic acid dien-20-oic acid

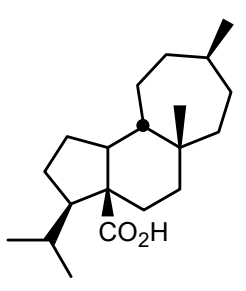

XXV. $13 \alpha(H)$-mulinan-20-oic acid

Figure A1. Cont. 


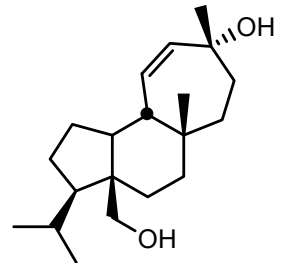

XXVI. Mulinol

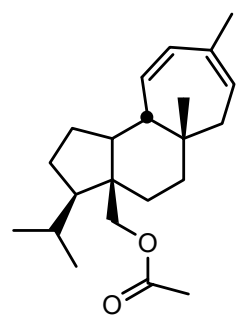

XXX. 20-Acetoxymulina11,13-diene<smiles>CC(C)[C@H]1CC[C@H]2C3C=C[C@@](C)(O)C(=O)C[C@]3(C)CC[C@@]21C(=O)O</smiles>

XXXIV. $13 \alpha-$ Hydroxy-14oxomulin-11-en-20-oic acid

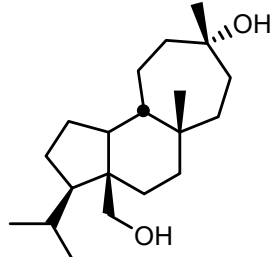

XXVII. Dihydromulinol

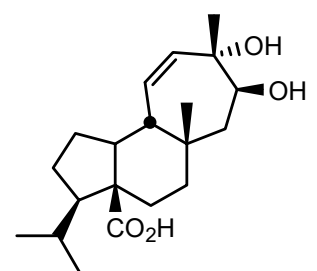

XXXI. $13 \alpha, 14 \beta$-Dihydroxymulin-11-en-20-oic acid

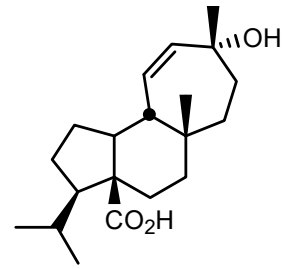

XXVIII. 13 $\alpha$-Hydroxymulin11-en-20-oic acid

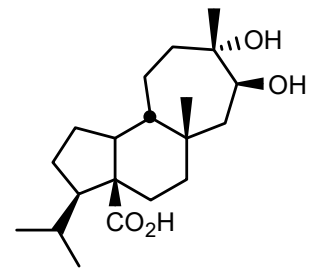

XXXII. $13 \alpha, 14 \beta$-Dihydroxymulinan-20-oic acid

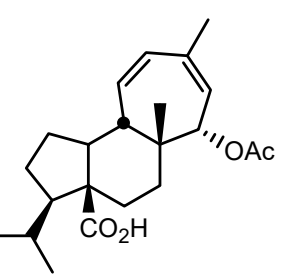

XXXV. 7 $\beta, 13 \alpha$-Dihydroxy- XXXVI. 15 $\alpha$-Acetoxymulina mulin-11-ene

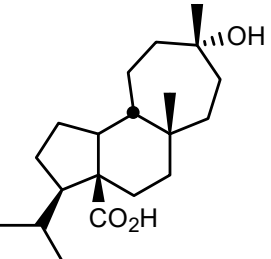

XXIX. $13 \alpha-H y d r o x y-$ mulinan-20-oic acid

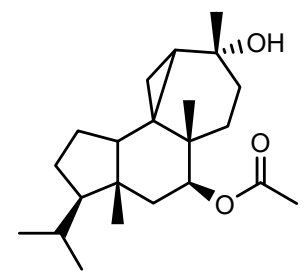

XXXIII. Azorellano

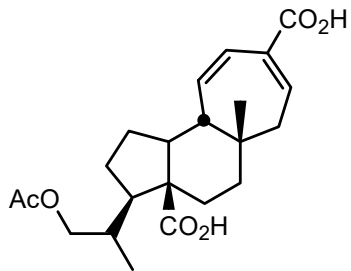

XXXVII. 18-Acetoxymulina -11,13-dien-16,20-dioic acid

Figure A1. Chemical structures cited and listed in Table 1.

\section{References}

1. Johns, R.B. Biological Markers in the Sedimentary Record; Elsevier: Amsterdam, The Netherlands, $1986 ;$ p. 364.

2. Simoneit, B.R.T. The organic chemistry of marine sediments. In Chemical Oceanography, 2nd ed.; Riley, J.P., Chester, R., Eds.; Academic Press: New York, NY, USA, 1978; Volume 7, pp. 233-311.

3. Simoneit, B.R.T. Organic matter of the troposphere-V: Application of molecular marker analysis to biogenic emissions into the troposphere for source reconciliations. J. Atmos. Chem. 1989, 8, 251-275. [CrossRef]

4. Simoneit, B.R.T. A review of biomarker compounds as source indicators and tracers for air pollution. Environ. Sci. Pollut. Res. 1999, 6, 153-163. [CrossRef] [PubMed]

5. Simoneit, B.R.T.; Mazurek, M.A. Organic matter of the troposphere-II: Natural background of biogenic lipid matter in aerosols over the rural western United States. Atmos. Environ. 1982, 16, 2139-2159. [CrossRef]

6. Otto, A.; White, J.D.; Simoneit, B.R.T. Natural product terpenoids in Eocene and Miocene conifer fossils. Science 2002, 297, 1543-1545. [CrossRef] [PubMed]

7. Medeiros, P.M.; Simoneit, B.R.T. Multi-biomarker characterization of sedimentary organic carbon in small rivers draining the northwestern United States. Org. Geochem. 2008, 39, 52-74. [CrossRef]

8. Simoneit, B.R.T.; Halpern, H.I.; Didyk, B.M. Lipid productivity of a high Andean lake. In Biogeochemistry of Ancient and Modern Environments; Trudinger, P.A., Walter, M.R., Ralph, B.J., Eds.; Australian Academy of Sciences: Canberra, Australia, 1980; pp. 201-210.

9. Muñoz, C. Sinopsis de la Flora Chilena, 2nd ed.; Edition de la Universidad de Chile: Santiago, Chile, 1966; p. 500.

10. Simoneit, B.R.T.; Didyk, B.M. The lipid and resin composition of Laretia compacta Phil. from the Andes of Chile. Z. Naturforsch. C 1999, 54, 309-313. [CrossRef]

11. Nicolas, A.N.; Plunkett, G.M. Untangling generic limits in Azorella, Laretia, and Mulinum (Apiaceae: Azorelloideae): Insights from phylogenetics and biogeography. Taxon 2012, 61, 826-840. [CrossRef]

12. Creceau-Larrival, M.-T. Morphologie pollinique et corrélation phytogénétique chez les Ombelifères. In The Biology and Chemistry of the Umbelliferae; Heywood, V.H., Ed.; Academic Press: London, UK, 1971; pp. 109-135. 
13. Saldivia, P.; Faundez, L.; Urbina-Casanova, R.; Scherson, R.A. Demeykoa andina (Apiaceae; Azorelloideae), a new species from northern Chile. Syst. Bot. 2016, 41, 457-463. [CrossRef]

14. Suárez Contreras, I. Contribución al estudio Botánico y Químico de le Laretia compacta Phil. (Llareta); Facultad de Biología y Ciencias Médicas, Universidad de Chile: Santiago, Chile, 1935.

15. Wickens, G.E. Llareta (Azorella compacta, Umbelliferae): A review. Econ. Bot. 1995, 49, 207-212. [CrossRef]

16. Loyola, L.A.; Morales, G.; Rodríguez, B.; Jiménez-Barbero, J.; de la Torre, M.C.; Perales, A.; Torres, M.R. Mulinic and isomulinic acids, rearranged diterpenes with a new carbon skeleton from Mulinum crassifolium. Tetrahedron 1990, 46, 5413-5420. [CrossRef]

17. Loyola, L.A.; Morales, G.; de la Torre, M.C.; Pedreros, S.; Rodríguez, B. 17-Acetoxymulinic acid, a rearranged diterpenoid from Mulinum crassifolium. Phytochemistry 1990, 29, 3950-3951. [CrossRef]

18. Loyola, L.A.; Morales, G.; Rodríguez, B.; Jiménez-Barbero, J.; Pedreros, S.; de la Torre, M.C.; Perales, A. Mulinenic acid a rearranged diterpenoid from Mulinum crassifolium. J. Nat. Prod. 1991, 54, 1404-1408. [CrossRef]

19. Loyola, L.A.; Bórquez, J.; Morales, G.; San-Martín, A. Diterpenoids from Azorella compacta. Phytochemistry 1997, 44, 649-651. [CrossRef]

20. Loyola, L.A.; Bórquez, J.; Morales, G.; San-Martín, A. Mulinol, a diterpenoid from Azorella compacta. Phytochemistry 1997, 45, 1465-1467. [CrossRef]

21. Loyola, L.A.; Bórquez, J.; Morales, G.; San-Martín, A.; Manríquez, V.; Wittke, O. Azorellanol: A diterpenoid with a new carbon skeleton from Azorella compacta. Tetrahedron 1998, 54, 15533-15540. [CrossRef]

22. Loyola, L.A.; Bórquez, J.; Morales, G.; San-Martín, A. 11,12-Epoxy-mulin-13-en-20-oic acid, a diterpenoid from Azorella compacta. Phytochemistry 1998, 49, 1091-1093. [CrossRef]

23. Loyola, L.A.; Bórquez, J.; Morales, G.; Araya, J.; González, J.; Neira, I.; Sagua, H.; San-Martín, A. Diterpenoids from Azorella yareta and their trichomonicidal activities. Phytochemistry 2001, 56, 177-180. [CrossRef]

24. Loyola, L.A.; Bórquez, J.; Morales, G.; San-Martín, A.; Darias, J. Madreporanone, a unique diterpene with a novel skeleton from Azorella madreporica. Tetrahedr. Lett. 2002, 43, 6359-6362. [CrossRef]

25. Loyola, L.A.; Bórquez, J.; Morales, G.; San-Martín, A.; Manríquez, V.; Boys, D.; Darias, J. Yaretol, a norditerpenoid from Azorella madreporica. J. Nat. Prod. 2002, 65, 1678-1680. [CrossRef]

26. Loyola, L.A.; Bórquez, J.; Morales, G.; San-Martín, A.; Darias, J.; Flores, N.; Giménez, A. Mulinane-type diterpenoids from Azorella compacta display antiplasmodial activity. Phytochemistry 2004, 65, 1931-1935. [CrossRef]

27. Nicoletti, M.; di Fabio, A.; d'Andrea, A.; Salvatore, G.; van Baren, C.; Coussio, J.D. Diterpenoid acids from Mulinum spinosum. Phytochemistry 1996, 43, 1065-1067. [CrossRef]

28. Wächter, G.A.; Matooq, G.; Hoffmann, J.J.; Maiese, W.M.; Singh, M.P.; Montenegro, G.; Timmermann, B.N. Antibacterial diterpenoid acids from Azorella compacta. J. Nat. Prod. 1999, 62, 1319-1321. [CrossRef] [PubMed]

29. Areche, C.; Rojas-Alvarez, F.; Campos-Briones, C.; Lima, C.; Pérez, E.G.; Sepúlveda, B. Further mulinane diterpenoids from Azorella compacta. J. Pharm. Pharmacol. 2013, 65, 1231-1238. [CrossRef] [PubMed]

30. Areche, C.; Sepúlveda, B.; San-Martín, A.; García-Beltrán, O.; Simirgiotis, M.; Cañete, A. An unusual mulinane diterpenoid from the Chilean plant Azorella compacta (Gaertn) Pers. Org. Biomol. Chem. 2014, 12, 6406-6413. [CrossRef] [PubMed]

31. Bórquez, J.; Ardiles, A.; Loyola, L.A.; Peña-Rodriguez, L.M.; Molina-Salinas, G.M.; Vallejos, J.; Collado, I.G.; Simirgiotis, M.J. Further mulinane and azorellane diterpenoids isolated from Mulinum crassifolium and Azorella compacta. Molecules 2014, 19, 3898-3908. [CrossRef] [PubMed]

32. Bórquez, J.; Bartolucci, N.L.; Echiburú-Chau, C.; Winterhalter, P.; Vallejos, J.; Jerz, G.; Simirgiotis, M.J. Isolation of cytotoxic diterpenoids from the Chilean medicinal plant Azorella compacta Phil from the Atacama Desert by high-speed counter-current chromatography. J. Sci. Food Agric. 2015, 96, 2832-2838. [CrossRef] [PubMed]

33. Salgado, F.; Areche, C.; Sepúlveda, B.; Simirgiotis, M.J.; Caceres, F.; Quispe, C.; Quispe, L.; Cano, T. A new mulinane diterpenoid from the cushion shrub Azorella compacta growing in Peru. Pharmacog. Mag. 2014, 10, S542-S548. [CrossRef]

34. Sepúlveda, B.; Quispe, C.; Simirgiotis, M.; García-Beltrán, O.; Areche, C. Gastroprotective effects of new diterpenoid derivatives from Azorella cuatrecasasii Mathias \& Constance obtained using a $\beta$-cyclodextrin complex with microbial and chemical transformations. Bioorg. Med. Chem. Lett. 2016, 26, 3220-3222. 
35. San-Martín, A.; Bacho, M.; Núñez, S.; Rovirosa, J.; Soler, A.; Blanc, V.; León, R.; Olea, A.F. A novel normulinane isolated from Azorella compacta and assessment of its antibacterial activity. J. Chil. Chem. Soc. 2018, 63, 4082-4085. [CrossRef]

36. Liu, Y.-T.; Li, L.-P.; Xie, J.-H.; Zhou, Q.-L. Divergent asymmetric total synthesis of mulinane diterpenoids. Angew. Chem. Int. Edit. 2017, 56, 12708-12711. [CrossRef]

37. Reber, K.P.; Xu, J.; Guerrero, C.A. Synthesis of mulinane diterpenoids. J. Org. Chem. 2015, 80, $2397-2406$. [CrossRef]

38. Noble, R.A.; Alexander, R.; Kagi, R.I.; Knox, J. Tetracyclic diterpenoid hydrocarbons in some Australian coals, sediments and crude oils. Geochim. Cosmochim. Acta 1985, 49, 2141-2147. [CrossRef]

39. Noble, R.A.; Alexander, R.; Kagi, R.I.; Knox, J. Identification of some diterpenoid hydrocarbons in petroleum. Org. Geochem. 1986, 10, 825-829. [CrossRef]

40. Shareef, A.; Angrove, M.J.; Wells, J.D. Optimization of silylation using N-methyl-N(trimethylsilyl)-trifluoroacetamide, $\quad \mathrm{N}, \mathrm{O}$-bis-(trimethylsilyl)-trifluoroacetamide $\quad$ and $\mathrm{N}$-(tertbutyldimethylsilyl)- $N$-methyltrifluoroactamide for the determination of the estrogens estrone and $17 \alpha$-ethinylestradiol by gas chromatography-mass spectrometry. J. Chromatogr. A 2006, 1108, 121-128. [PubMed]

41. Kühnel, E.; Laffan, D.D.P.; Lloyd-Jones, G.C.; Martínez del Campo, T.; Shepperson, I.R.; Slaughter, J.L. Mechanism of methyl esterification of carboxylic acids by trimethylsilyldiazomethane. Angew. Chem. Int. Ed. 2007, 46, 7075-7078. [CrossRef] [PubMed]

42. Kovats, E. Gas-chromatographische Charakterisierung organischer Verbindungen. Teil 1: Retentionsindices aliphatischer Halogenide, Alkohole, Aldehyde und Ketone. Helv. Chim. Acta 1958, 41, 1915-1932. [CrossRef]

Sample Availability: Not available.

(C) 2019 by the authors. Licensee MDPI, Basel, Switzerland. This article is an open access article distributed under the terms and conditions of the Creative Commons Attribution (CC BY) license (http:/ / creativecommons.org/licenses/by/4.0/). 